\title{
PENGARUH STRUKTUR KEPEMILIKAN SAHAM TERHADAP KEBIJAKAN DIVIDEN (STUDI PADA PERUSAHAAN-PERUSAHAAN YANG TERDAFTAR DI BURSA EFEK INDONESIA)
}

\author{
Drs. Saut Purba, MM \\ Dr. Donalson Silalahi
}

\begin{abstract}
Dividend policy is an interesting theme in financial research. The dividend policy often used to reduce conflicts of interest between shareholders and managers. Therefore, would be argued that the ownership structure affect the dividend policy.

This study aims to: First, to explain the ownership structure and dividend policy. Second, to obtain the empirical evidence about the impact of ownership structure on dividend policy by used size, capital structure and profitability of the firm as control variables.

The study was conducted in Indonesia Stock Exchange using the 198 companies as samples and use multiple regression as an analytical tool. Based on the results of the study suggested that: First, the institutional ownership before and after the control variables included positive and significant effect on the dividend payout ratio. Second, managerial ownership before and after the control variables included no significant effect on the dividend payout ratio. Third, the size of the company have significant positive effect on the dividend payout ratio. Fourth, capital structure and profitability of the firm has no significant effect on the dividend payout ratio.

Key Words: Ownership structure, dividend policy, conflict of interest.
\end{abstract}

\section{PENDAHULUAN}

Kebijakan dividen merupakan tema yang menarik dalam riset keuangan disebabkan kebijakan dividen merupakan topik yang kontroversial. Para akademisi telah melakukan penjelasan dan menghasilkan sejumlah teori serta perhatian lebih tentang kebijakan dividen di pasar modal yang sudah maju tetapi masih relatif terbatas di pasar modal yang sedang berkembang.

Bagaimanapun, teori dan pemahaman yang lebih sempurna tentang kebijakan dividen akan didapatkan dengan melakukan penelitian di pasar modal yang sedang berkembang. Pasar modal Indonesia merupakan salah satu pasar modal yang sedang berkembang. Oleh karena itu, sangat penting dilakukan penelitian tentang kebijakan dividen di pasar modal Indonesia.

Dewasa ini, kebijakan dividen telah digunakan sebagai sarana pengawasan untuk mereduksi konflik kepentingan antara shareholders dan managers. Hal ini sejalan dengan pendapat yang dikemukakan oleh Jensen (1986), bahwa masalah agensi dapat direduksi dengan mempergunakan kebijakan dividen. Dengan demikian, dapat dikemukakan bahwa struktur kepemilikan saham mempengaruhi kebijakan dividen perusahaan.

Kepemilikan saham suatu perusahaan sangat bervariasi dan tegantung dari seberapa besar saham yang dimiliki dan status kepemilikannya. Pada dasarnya, shareholders berperan dalam membuat keputusan penting perusahaan. Park (2009) mengemukakan bahwa jika porsi kepemilikan saham lebih besar dari 1 (satu) persen, maka posisi pemegang saham begitu penting dalam mempengaruhi perusahaan. Sebaliknya, jika posisi kepemilikan saham lebih rendah dari 1 (satu) persen, maka peranan mereka tidak begitu penting dalam mempengaruhi perusahaan. Oleh karena itu, maka secara relatif hanya kelompok institusi yang dimungkinkan memiliki porsi kepemilikan saham yang lebih besar dari 1 (satu) persen. Dengan demikian, dalam penelitian ini kepemilikan saham perusahaan dibatasi hanya pada kepemilikan institusional dan kepemilikan manajerial. 
Kepemilikan institusional suatu perusahaan telah menunjukkan perkembangan yang cukup pantastis. Jennings et al. (2002) mengemukakan bahwa pada tahun 1945 sebesar 5 persen ekuitas perusahaan dimiliki oleh institusi, pada tahun 1965 meningkat menjadi 24 persen, pada tahun 1981 meningkat menjadi 38 persen, dan pada tahun 1993 sudah lebih dari 50 persen. Demikian juga halnya dengan kepemilikan institusional di pasar modal Indonesia telah mendominasi kepemilikan saham-saham perusahaan yang terdaftar di Bursa Efek Indonesia (ECFIN: 2011). Fenomena ini menggambarkan bahwa peranan kepemilikan institusional dalam memonitor perusahaan telah menunjukkan peningkatan hingga saat ini sehingga menjadi sangat penting diteliti dampaknya terhadap kebijakan dividen di bursa efek Indonesia.

Di samping bentuk kepemilikan institusional, bagaimanapun, managers dan board of directors juga berperan dalam memonitor performance perusahaan. Oleh karenanya, kepemilikan manajerial juga dipergunakan sebagai variabel dalam penelitian ini. Selain berperan dalam memonitor performance perusahaan, manajer perusahaan cenderung lebih menyukai laba perusahaan ditahan untuk meningkatkan pengawasannya terhadap sumber daya perusahaan, dan disisi lain, kebijakan dividen dapat dipergunakan untuk mereduksi biaya agensi sehingga menjadi sangat penting diteliti dampak dari kepemilikan manajerial terhadap kebijakan dividen.

Dalam menjelaskan dampak struktur kepemilikan saham perusahaan (kepemilikan institusional dan kepemilikan manajerial) terhadap kebijakan dividen di bursa efek Indonesia, dipergunakan juga variabel kontrol, yaitu: ukuran perusahaan (size), struktur modal, dan profitabilitas perusahaan. Variabel kontrol ini dimaksudkan untuk mengontrol hubungan kausal antara kepemilikan institusional dan manajerial terhadap kebijakan dividen.

Dengan berpedoman pada paparan tersebut, maka penelitian ini bertujuan untuk: Pertama, menjelaskan struktur kepemilikan saham (institusi dan manajerial) di Bursa Efek Indonesia. Kedua, menjelaskan kebijakan dividen di Bursa Efek Indonesia. Ketiga, mendapatkan bukti empiris tentang dampak kepemilikan institusional terhadap kebijakan dividen dengan mempergunakan ukuran perusahaan, struktur modal, dan profitabilitas perusahaan sebagai variabel kontrol di Bursa Efek Indonesia. Keempat, mendapatkan bukti empiris tentang dampak kepemilikan manajerial terhadap kebijakan dividen dengan mempergunakan ukuran perusahaan, struktur modal, dan profitabilitas perusahaan sebagai variabel kontrol di Bursa Efek Indonesia.

\section{TINJAUAN PUSTAKA}

Pada dasarnya manajer keuangan suatu perusahaan melaksanakan tiga keputusan, yaitu: keputusan investasi, keputusan pembiayaan, dan keputusan dividen. Ketiga keputusan tersebut dilaksanakan pimpinan perusahaan untuk menciptakan nilai bagi shareholders (Van Horne: 1991).

Kebijakan dividen merupakan salah satu kebijakan penting dalam corporate finance. Perusahaan memandang kebijakan dividen sebagai keputusan penting disebabkan kebijakan tersebut berperan dalam menentukan seberapa besar dana yang akan disampaikan kepada investor dalam bentuk dividen dan seberapa besar dana tersebut ditahan dalam perusahaan untuk membiayai projek-projek investasi.

Arshad et al. (2013) mengemukakan terdapat beberapa teori yang mendukung argumentasi, mengapa perusahaan melakukan pembayaran dividen kepada shareholders. Tori tersebut adalah teori bird-in-the-hand, agency theory, dan teori signalling.

Menurut teori bird-in-the-hand bahwa outside shareholder lebih menyukai dividen tunai dari pada capital gain. Oleh karenanya, outside shareholder lebih menyukai kebijakan dividen atau 
dividend payout ratio yang besar dan dengan demikian laba ditahan sebagai sumber pembiayaan projek-projek investasi semakin rendah.

Jensen dan Meckling (1976) mengemukakan bahwa hubungan agensi terjadi ketika dilakukan pemisahan antara ownership dan control perusahaan. Dengan demikian, agency cost muncul akibat terjadinya konflik kepentingan antara managers dengan owners. Konflik kepentingan yang berkepanjangan akan berdampak negatip terhadap eksistensi perusahaan. Oleh karenanya, untuk keberlangsungan hidup perusahaan, konflik kepentingan tersebut harus ditanggulangi. Dalam menanggulangi konflik kepentingan tersebut, Short et al. (2002) mengemukakan bahwa kebijakan dividen berperan penting dalam mereduksi agency costs yang muncul dari konflik kepentingan antara managers dan owners.

Teori Signaling berhubungan dengan ide bahwa agents mengirimkan informasi kepada principal untuk meningkatkan kredibilitas hubungan antara agent dengan principal. Dalam hal ini manajer memiliki informasi yang lengkap tentang perusahaan yang dipimpinnya, sementara investor tidak memiliki informasi selengkap informasi yang dimiliki oleh manajer, dan manajer selalu enggan untuk transparan kepada shareholders tentang informasi perusahaan. Oleh karena itu, kebijakan dividen dapat dipergunakan untuk tujuan informasi dan juga sebagai signal adanya proyek-proyek yang menjanjikan dimasa depan.

Menurut Bhattacharya (1980) bahwa dividen menggambarkan suatu signal tentang cash flows di masa depan, Lebih lanjut, Li dan Zhao (2008) berargumentasi bahwa kebijakan dividen memegang peranan penting disebabkan kebijakan dividen dapat dipergunakan untuk menyampaikan informasi kepada shareholders dan juga dipandang sebagai signal yang kuat.

\section{Struktur Kepemilikan Saham dan Kebijakan Dividen}

Struktur kepemilikan saham perusahaan dapat dipergunakan sebagai suatu mekanisme dalam menyelaraskan kepentingan antara shareholders dan managers. Struktur kepemilikan saham perusahaan sangat bervariasi, dan tegantung dari seberapa besar saham yang dimiliki dan status kepemilikannya. Dalam penelitian ini, struktur kepemilikan saham perusahaan hanya dibatasi pada kepemilikan institusional dan kepemilikan manajerial.

Investor institusional merupakan investor besar, seperti: bank, perusahaan investasi, perusahaan asuransi, dan institusi keuangan lainnya yang memiliki dana dalam jumlah relatif besar yang dapat diinvestasikan dalam sejumlah saham perusahaan yang berbeda. Oleh karenanya, investor-investor seperti ini sangat mempengaruhi corporate governance roles dimana corporate governance pada dasarnya berperan dalam mereduksi agency cost.

Berbagai penelitian telah dilakukan, diantaranya: Shleifer dan Vishny (1986) menunjukkan bahwa struktur kepemilikan saham berhubungan positip dengan kebijakan dividen; Zeckhauser dan Pound (1990) menemukan tidak terdapat perbedaan yang signifikan antara perusahaan-perusahaan dengan hadirnya atau tidak hadirnya large shareholders; Short et al. (2002) menunjukkan terdapat hubungan yang positip dan signifikan antara kepemilikan institusional dengan kebijakan dividen, dan Wen dan Jia (2010) menemukan bahwa institutional ownership memiliki hubungan yang negatip dengan dividend policy.

Jensen dan Meckling (1976) mengemukakan bahwa hubungan agensi terjadi ketika dilakukan pemisahan antara ownership dan control perusahaan. Dengan demikian, agency cost muncul sebab terjadi konflik kepentingan antara managers dengan owners. Biaya agensi dapat diturunkan jika kepemilikan saham insider (managers, directors, dan executive officers yang lain) meningkat sebab kenaikan kepemilikan saham insider dapat membantu menyelaraskan kepentingan managers dan shareholders. Dengan proporsi managerial ownership, penggunaan dividen sebagai alat untuk menurunkan biaya agensi dapat diturunkan (Al-Malkawi: 2007). 
Selanjutnya, Jensen (1986) berpendapat bahwa manajer lebih menyukai laba ditahan daripada laba tersebut didistribusikan kepada shareholders dalam bentuk dividen. Hal ini terjadi karena, manajer mempergunakan sumberdaya tersebut untuk menumbuhkan perusahaan dalam memperoleh manfaat personal. Pendapat tersebut didukung hasil penelitian empiris yang dilakukan oleh Eckbo dan Verma (1994). Hasil penelitiannya menunjukkan bahwa dividen mengalami penurunan bersamaan dengan meningkatnya managerial ownership dan juga dikemukakan bahwa manajer mengendalikan perusahaan pada saat mereka memiliki absolute voting power, sehingga pembayaran cash dividend adalah zero. Jensen et al (1992) menemukan bahwa kepemilikan insider yang lebih besar lebih menyukai kebijakan dividen dan hutang yang rendah.

Analisis yang dilakukan oleh Short et al. (2002) menemukan bahwa managerial ownership dan dividend payout policy memiliki hubungan yang negatip; Chen et al. (2005) juga menunjukkan terdapat hubungan yang negatip antara managerial ownership dengan dividend policy; Wen dan Jia (2010) menemukan bahwa managerial ownership memiliki hubungan yang negatip dengan dividend policy; dan Mehrani et al. (2011) menemukan hubungan negatip antara managerial ownership dengan dividend payment policy.

Hubungan Kausal antara Ukuran Perusahaan, Struktur Modal, dan Profitabilitas dengan Kebijakan Dividen

Dalam berbagai literatur dikemukakan bahwa size perusahaan berhubungan negatip dengan probabilias kebangkrutan suatu perusahaan (Rajan dan Zingales: 1995). Kondisi ini terjadi disebabkan perusahaan-perusahaan besar cenderung terdiversifikasi sehingga perusahaan cenderung memiliki kemampuan dalam membayar dividen dalam jumlah yang lebih besar. Berdasarkan pendapat tersebut dapat dikemukakan bahwa ukuran perusahaan memiliki hubungan kausal yang positip dengan dividend payout ratio.

Selain size perusahaan, struktur modal (leverage) juga dipergunakan sebagai variabel kontrol. Leverage dipergunakan sebagai variabel kontrol disebabkan leverage dapat meningkatkan shareholders return tetapi dengan tingkat risiko yang lebih besar untuk menghindari likuidasi dan mempertahankan posisi likuiditas serta arus kas yang pada akhirnya akan mempengaruhi pembayaran dividen. Dengan demikian dapat dikemukakan bahwa leverage diharapkan memiliki hubungan kausal yang negatip dengan dividend payout ratio.

Menurut Jensen dan Meckling (1976), dan Jensen (1986), leverage keuangan berperan penting dalam memonitor manajer sehingga berperan dalam mereduksi agency cost dari konflik antara shareholders dan managers sehingga meningkatkan nilai perusahaan. Jensen (1986) menyimpulkan bahwa penggunaan debt dapat mereduksi kebutuhan penggunaan dividend untuk mengurangi konflik sehingga diprediksi hubungan kausal negatip antara debt dan dividend.

Variabel kontrol berikutnya adalah profitabilitas perusahaan. Perusahaan-perusahaan yang berhasil menghasilkan laba akan terhindar dari kebangkrutan sehingga diharapkan bahwa profitabilitas perusahaan berhubungan positip dengan kebijakan dividen. Oleh karenanya, dirumuskan paradigma bahwa terdapat hubungan kausal yang positip antara profitabilitas perusahaan dengan dividend payout ratio.

\section{METODE PENELITIAN}

Dalam penelitian ini, variabel yang dipergunakan terdiri dari: dividend payout ratio, kepemilikan institusional, kepemilikan manajerial, ukuran perusahaan, struktur modal, dan profitabilitas perusahaan. Sebagai variabel tidak bebas adalah Dividend Payout Ratio (DPR). 
Dividend Payout Ratio (DPR) telah banyak dipergunakan sebagai proksi dari kebijakan dividen (Ahmed dan Attiya, 2009). Dividend Payout Ratio (DPR) merupakan perbandingan antara dividen per lembar saham dengan pendapatan per lembar saham.

Sebagai variabel bebas dalam penelitian ini adalah Kepemilikan Institusional (KI), Kepemilikan Manajerial (KM), Ukuran Perusahaan (UP), Struktur Modal (SM), dan Profitabilitas Perusahaan (PP). Kepemilikan Institusional (KI) menggambarkan persentase kepemilikan saham oleh institusi, seperti: lembaga keuangan perbankan, perusahaan asuransi, dana pensiun, koperasi, yayasan atau perusahaan lain. Kepemilikan institusional diukur dengan membandingkan jumlah saham yang dimiliki oleh semua institusi dengan jumlah saham yang terdaftar untuk masing-masing perusahaan yang menjadi sampel penelitian.

Kepemilikan Manajerial (KM) merupakan persentase saham perusahaan yang dimiliki oleh Board of Directors (BOD) dan Executive Officers. Biaya agensi dapat diturunkan jika kepemilikan saham insider (managers, directors, dan executive officers yang lain) meningkat sebab kenaikan kepemilikan saham insider dapat membantu menyelaraskan kepentingan managers dan shareholders (Jensen dan Meckling: 1976).

Variabel kontrol adalah Ukuran Perusahaan (UP), Struktur Modal (SM), dan Profitabilitas Perurahaan (PP). Ukuran Perusahaan (UP) dimanifestasikan oleh logaritma natural dari total assets (Beiner et al. : 2006).

Struktur Modal (SM) berperan penting dalam memonitor manajer sehingga berperan dalam mereduksi agency cost dari konflik antara shareholders dengan managers. Struktur Modal (SM) dimanifestasikan oleh rasio antara jumlah utang dengan jumlah ekuitas (Kouki dan Guizani : 2009).

Profitabilitas Perusahaan (PP) menggambarkan kemampuan perusahaan dalam menghasilkan laba dengan mempergunakan semua assets perusahaan. Oleh karenanya, Profitabilitas Perusahaan (PP) dimanifestasikan oleh rasio antara laba bersih dengan total assets.

Populasi dalam penelitian ini adalah semua perusahaan yang terdaftar di Bursa Efek Indonesia pada akhir tahun 2011. Jumlah perusahaan yang terdaftar di Bursa Efek Indonesia pada akhir tahun 2011 sebanyak 428 perusahaan. Dengan mengeliminasi perusahaanperusahaan yang baru mengemisikan sahamnya pada periode penelitian, perusahaanperusahaan yang sahamnya jarang diperdagangkan, dan perusahaan-perusahaan yang tidak memiliki data lengkap, maka sample size sebanyak 198 perusahaan. Dengan demikian, teknik pengambilan sampel dalam penelitian ini mempergunakan teknik purposive sampling (Indriantoro dan Supomo: 1999).

Data yang dipergunakan dalam penelitian ini adalah data sekunder, yaitu: data dividend per share, earnings per share, kepemilikan saham perusahaan (kepemilikan institusional dan kepemilikan manajerial), ukuran perusahaan (jumlah harta perusahaan), leverage ratio atau struktur modal perusahaan (total debt to total equity ratio), dan return on investment masingmasing perusahaan yang menjadi sampel penelitian dan terdaftar di Bursa Efek Indonesia pada 2011. Semua data tersebut didapatkan dari Indonesian Capital Market Directory Tahun 2011. Dengan demikian teknik pengambilan data adalah teknik dokumentasi.

Untuk menguji dampak kepemilikan saham terhadap kebijakan dividen dan dampak kepemilikan saham terhadap kebijakan dividen dengan memasukkan variabel kontrol dipergunakan model berikut ini.

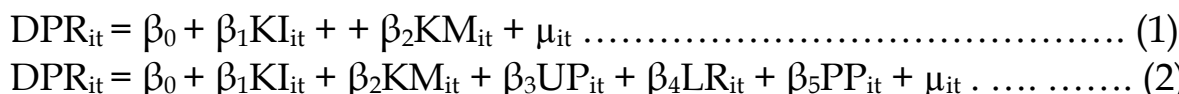

dimana: $\mathrm{DPR}_{\mathrm{it}}=$ Dividend Payout Ratio perusahaan i pada periode $\mathrm{t}$

$\mathrm{KI}_{\mathrm{it}}=$ Kepemilikan Institusional perusahaan i pada periode $\mathrm{t}$ 
$\mathrm{KM}_{\mathrm{it}}=$ Kepemilikan Manajerial perusahaan i pada periode $\mathrm{t}$

$\mathrm{UP}_{\text {it }}=$ Ukuran perusahaan $\mathrm{i}$ pada periode $\mathrm{t}$

$\mathrm{LR}_{\mathrm{it}}=$ Leverage Ratio perusahaan i pada periode $\mathrm{t}$

$\mathrm{PP}_{\mathrm{it}}=$ Profitabilitas Perusahaan i pada periode $\mathrm{t}$

$\mu_{\text {it }}=$ Stochastic or disturbance term.

$\beta_{0}=$ Konstanta,

$\beta_{1}, \beta_{2}, \beta_{3}, \beta_{4} \beta_{5}$, koefisien regressi Kepemilikan Institusional (KI), Kepemilikan Manajerial (KM), Ukuran Perusahaan (UP), Struktur Modal (SM), dan Profitabilitas Perusahaan (PP).

Model (1) mempergunakan Kepemilikan Institusional (KI) dan Kepemilikan Manajerial (KM) sebagai variabel independen. Model (2) mempergunakan Kepemilikan Institusional (KI) dan Kepemilikan manajerial (KM) serta variabel kontrol sebagai variabel independen. Metode ini dipergunakan untuk melihat konsistensi arah hubungan kausal dari kepemilikan Institusional (KI) dan Kepemilikan Manajerial (KM) dengan Dividend Payout Ratio (DPR). Selanjutnya, untuk menjelaskan hubungan kausal atau dampak struktur kepemilikan saham terhadap dividen payout ratio (DPR) perusahaan tanpa atau dengan mempergunakan ukuran perusahaan (UP), struktur modal (SM), dan profitabilitas perusahaan (PP) sebagai variabel kontrol dipergunakan uji t dengan a sebesar 10 persen.

Selanjutnya, untuk menjelaskan pengaruh secara serentak variabel bebas terhadap variabel tidak bebas dipergunakan uji $\mathrm{F}$ dengan a sebesar 10 persen, dan besaran kontribusi dari struktur kepemilikan terhadap kebijakan dividen ditunjukkan oleh nilai R². Selanjutnya, dalam mengolah data dipergunakan program SPSS Version 18.

\section{Deskripsi Variabel Penelitian}

\section{HASIL PENELITIAN DAN PEMBAHASAN}

Deskripsi variabel penelitian yang berhubungan dengan Kepemilikan Institusi (KI), Kepemilikan Manajerial (KM), Struktur Modal (SM), Ukuran Perusahaan (UP), Profitability Perusahaan (PP), dan Dividen Payout Ratio (DPR) perusahaan-perusahaan yang menjadi sampel dalam penelitian ini dapat dilihat pada Tabel 1 berikut.

Tabel 1. Deskripsi Data Variabel Penelitian

\begin{tabular}{|c|c|c|c|c|c|c|c|}
\hline & $\mathrm{KI}$ & KM & $\mathrm{SM}$ & UP & $\mathrm{PP}$ & DPR \\
\hline \multirow[t]{3}{*}{$\mathrm{N}$} & Valid & 198 & 198 & 198 & 198 & 198 & 198 \\
\hline & Missin & 0 & 0 & 0 & 0 & 0 & 0 \\
\hline & $\mathrm{g}$ & & & & & & \\
\hline $\mathrm{Me}$ & & 65.30143 & 1.09186 & 1.36345 & 3283.56769 & 12.46635 & 9.03440 \\
\hline Std & eviation & 26.428393 & 3.565221 & 2.371256 & 5721.081711 & 111.78561 & 26.7648 \\
\hline $\mathrm{Mi}$ & $\mathrm{um}$ & .001 & .000 & .001 & .009 & -37.650 & .000 \\
\hline $\mathrm{Ma}$ & um & 99.920 & 28.400 & 27.060 & 30742.000 & 1571.000 & 264.230 \\
\hline
\end{tabular}

Sumber: Hasil Penelitian dan Sudah Diolah.

\section{Pengaruh Kepemilikan Institusi dan Kepemilikan Manajerial terhadap Dividen Payout Ratio}

Berdasarkan model analisis yang telah dikemukakan bahwa untuk menjelaskan pengaruh Kepemilikan Institusi (KI) dan Kepemilikan Manajerial (KM) terhadap Dividen Payout Ratio (DPR) dipergunakan 2 (dua) model. Model pertama adalah tanpa memasukkan variabel kontrol terhadap model analisis dan model kedua adalah dengan memasukkan variabel kontrol terhadap model analisis. Rekapitulasi hasil perhitungan pengaruh Kepemilikan Institusi (KI) 
dan Kepemilikan Manajerial (KM) terhadap Dividen Payout Ratio (DPR) tanpa mempergunakan variabel kontrol ditunjukkan pada Tabel 2 berikut ini.

Tabel 2. Rekapitulasi Hasil Penelitian Pengaruh Kepemilikan Institusi dan Kepemilikan Manajerial terhadap Dividen Payout Ratio

\begin{tabular}{|c|c|c|c|c|c|}
\hline \multicolumn{6}{|c|}{$\begin{array}{l}\text { Variabel Independen: Kepemilikan Institusi (KI) dan Kepemilikan Manajerial } \\
\quad(\mathrm{KM}) \\
\text { Metode: Least Square } \\
\text { Sampel : } 198 \text { Perusahaan } \\
\text { Model: } \mathrm{DPR}_{\mathrm{it}}=\beta_{0}+\beta_{1} \mathrm{KI}_{\mathrm{it}}+\beta_{2} \mathrm{KM}_{\mathrm{it}}+\mu_{\mathrm{it}}\end{array}$} \\
\hline \multirow{2}{*}{ Model } & \multicolumn{2}{|c|}{ Unstandarized Coefficients } & \multirow{2}{*}{$\begin{array}{c}\begin{array}{c}\text { Standarized } \\
\text { Coefficients }\end{array} \\
\text { Beta }\end{array}$} & \multirow{2}{*}{$\begin{array}{c}\mathrm{t}- \\
\text { Statistic }\end{array}$} & \multirow[t]{2}{*}{ Sig } \\
\hline & B & Std.Error & & & \\
\hline Konstanta & $-0,238$ & 5,224 & & $-0,046$ & 0,964 \\
\hline KI & 0,145 & 0,073 & 0,144 & 2,002 & 0,047 \\
\hline KM & $-0,202$ & 0,538 & $-0,027$ & $-0,375$ & 0,708 \\
\hline \multicolumn{2}{|c|}{$\begin{array}{l}R \text { Multipel } \\
R \text { Square } \\
\text { Adjusted } R \text { Square } \\
\text { Std. error of the Estimate }\end{array}$} & $\begin{array}{c}0,150 \\
0,023 \\
0,013 \\
26,596\end{array}$ & \multicolumn{2}{|l|}{$\begin{array}{l}\text { F-Statistic } \\
\text { Sig. }\end{array}$} & $\begin{array}{l}2,249 \\
0,108\end{array}$ \\
\hline
\end{tabular}

Sumber: Hasil Olahan Data Penelitian dengan Mempergunakan Program SPSS Version 18.

Berdasarkan Tabel 2 tersebut di atas, dapat dikemukakan bahwa nilai koefisien determinan sebesar 2,3 persen dan nilai F-statistik sebesar 2.249 dengan probabilitas sebesar 0,108. Artinya, secara bersama-sama bahwa Kepemilikan Institusi (KI) dan Kepemilikan Manajerial (KM) berpengaruh terhadap Dividen Payout Ratio (DPR).

Selanjutnya, nilai koefisien regressi standardisasi variabel Kepemilikan Institusi (KI) sebesar 0,144 dan nilai t-satistik sebesar 2,002 dengan probabilitas sebesar 0,047. Oleh karena itu, dapat dikemukakan bahwa Kepemilikan Institusi (KI) berpengaruh positip dan signifikan terhadap Dividen Payout Ratio (DPR). Artinya, setiap kenaikan Kepemilikan Institusional (KI) akan menaikkan Dividen Payout ratio (DPR).

Koefisien regressi standardisasi variabel Kepemilikan Manajerial (KM) adalah -0,037 dan nilai t-statistik adalah -0,375 dengan probabilitas 0,708. Oleh karena itu dapat dikemukakan bahwa Kepemilikan Manajerial (KM) tidak berpengaruh terhadap Dividen Payout Ratio (DPR).

Dengan mepergunakan variabel kontrol, rekapitulasi hasil perhitungan pengaruh Kepemilikan Institusi (KI), Kepemilikan Manajerial (KM), dan variabel kontrol terhadap Dividen Payout Ratio (DPR) ditunjukkan pada Tabel 3 berikut ini. 
Tabel 3. Rekapitulasi Hasil Penelitian Pengaruh Kepemilikan Institusi, Kepemilikan Manajerial, Ukuran Perusahaan, Struktur Modal, dan Profitability Perusahaan terhadap Dividen Payout Ratio

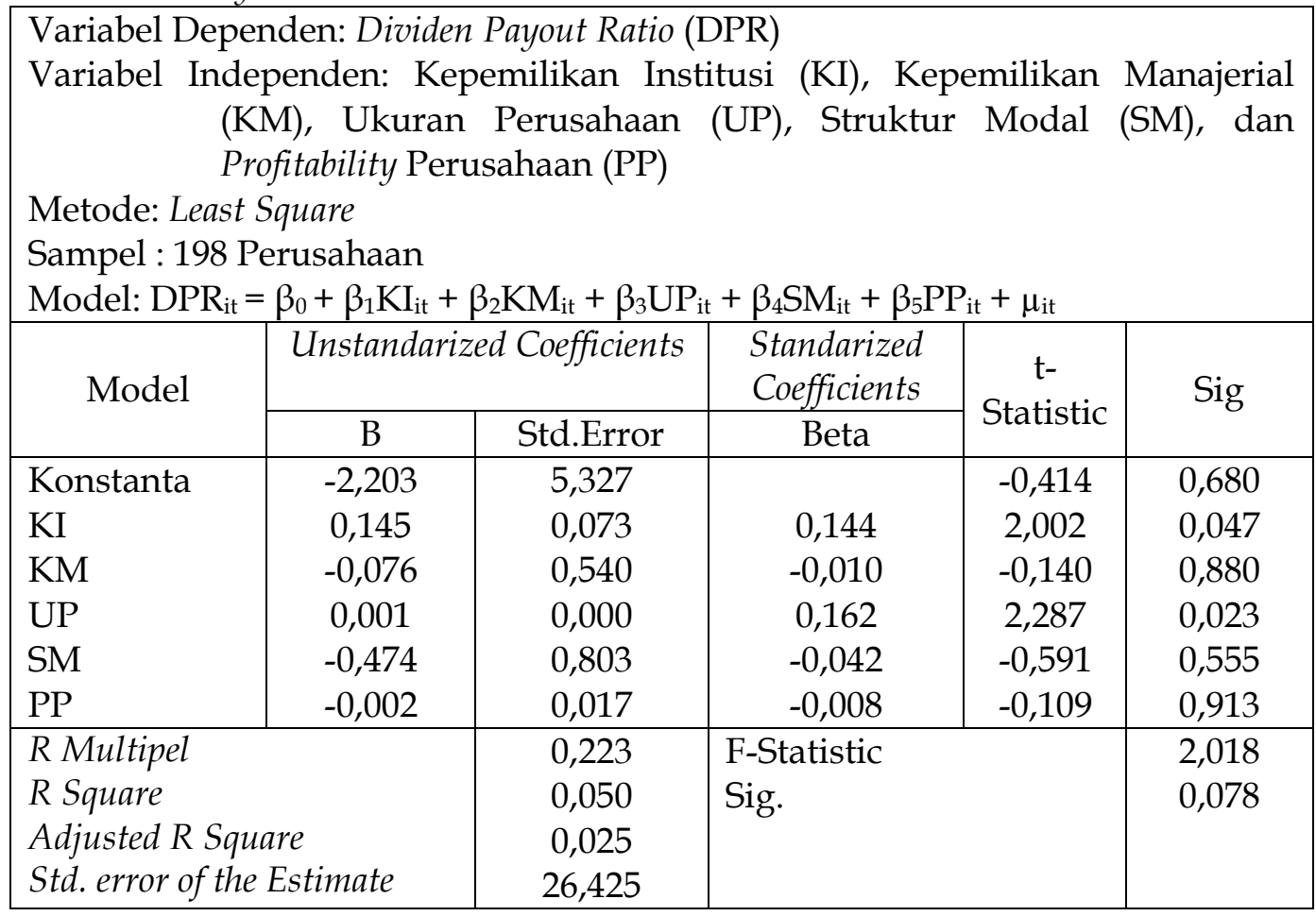

Sumber: Hasil Olahan Data Penelitian dengan Mempergunakan Program SPSS Version 18.

Berdasarkan Tabel 3 tersebut di atas, dapat dikemukakan bahwa nilai koefisien determinan sebesar 5 persen dengan nilai F-statistik adalah 2,018 dan probabilitas sebesar 0,078. Artinya, secara bersama-sama bahwa Kepemilikan Institusi (KI), Kepemilikan Manajerial (KM), Ukuran Perusahaan (UP), Struktur Modal (SM), dan Profitability Perusahaan (PP) mampu menjelaskan variabilitas Dividen Payout Ratio (DPR) sebesar 5 persen.

Selanjutnya, nilai koefisien regressi standardisasi variabel Kepemilikan Institusi (KI) sebesar 0,144 dengan nilai t-satistik sebesar 2,002 dan probabilitas sebesar 0,047. Oleh karena itu dapat dikemukakan bahwa Kepemilikan Institusi (KI) berpengaruh positip dan signifikan terhadap Dividen Payout Ratio (DPR). Artinya, setiap kenaikan Kepemilikan Institusional (KI) akan menaikkan Dividen Payout ratio (DPR).

Variabel bebas yang kedua adalah Kepemilikan Manajerial (KM). Berdasarkan Tabel 3 dapat dikemukakan bahwa nilai koefisien regressi standardisasi variabel Kepemilikan Manajerial (KM) sebesar -0,010 dengan nilai t-satistik sebesar -0,14 dan probabilitas sebesar 0,88. Dengan demikian dapat dikemukakan bahwa Kepemilikan Manajerial (KI) berpengaruh negatip dan tidak signifikan terhadap Dividen Payout Ratio (DPR). Artinya, setiap kenaikan Kepemilikan Manajerial (KI) akan menurunkan Dividen Payout ratio (DPR).

Variabel bebas yang ketiga adalah Ukuran Perusahaan (UP). Berdasarkan Tabel 3 dapat dikemukakan bahwa nilai koefisien regressi distandardisasi variabel Ukuran Perusahaan (UP) sebesar 0,162 dengan nilai t-satistik sebesar 2,287 dan probabilitas sebesar 0,023. Dengan mengacu pada informasi tersebut dapat dikemukakan bahwa Ukuran Perusahaan (UP) berpengaruh positip dan signifikan terhadap Dividen Payout Ratio (DPR). Artinya, setiap kenaikan Ukuran Perusahaan (UP) akan menaikkan Dividen Payout ratio (DPR). 
Variabel bebas yang keempat adalah Struktur Modal (SM). Berdasarkan Tabel 3 dapat dikemukakan bahwa nilai koefisien regressi standardisasi variabel Struktur Modal (SM) sebesar $-0,042$ dengan nilai $t$-satistik sebesar $-0,591$ dan probabilitas sebesar 0,555. Dengan mengacu pada informasi tersebut dapat dikemukakan bahwa Struktur Modal (SM) berpengaruh negatip dan tidak signifikan terhadap Dividen Payout Ratio (DPR). Artinya, setiap kenaikan Struktur Modal (SM) akan menurunkan Dividen Payout ratio (DPR).

Variabel bebas yang kelima adalah Profitability Perusahaan (PP). Berdasarkan Tabel 3 dapat dikemukakan bahwa nilai koefisien regressi standardisasi variabel Profitability Perusahaan (PP). sebesar -0,008 dengan nilai t-satistik sebesar -0,109 dan probabilitas sebesar 0,913. Dengan mengacu pada informasi tersebut dapat dikemukakan bahwa Profitability Perusahaan (PP). berpengaruh negatip dan tidak signifikan terhadap Dividen Payout Ratio (DPR). Artinya, setiap kenaikan Profitability Perusahaan (PP). akan menurunkan Dividen Payout ratio (DPR).

\section{Pembahasan}

Hubungan agensi terjadi ketika dilakukan pemisahan antara ownership dan control perusahaan. Dengan dilakukan pemisahaan tersebut, maka biaya agensi muncul sebab terjadi konflik kepentingan antara managers dengan owners. Managers lebih tertarik mengikuti strategi pertumbuhan untuk perusahaan yang dipimpinnya sebab pertumbuhan perusahaan akan memberikan power yang lebih besar baginya untuk mengontrol resources. Oleh karenanya, penting direduksi biaya agensi tersebut melalui kebijakan dividen. Artinya, struktur kepemilikan perusahaan dapat dipergunakan sebagai suatu mekanisme dalam menyelaraskan kepentingan antara shareholders dan managers.

Salah satu jenis shareholders adalah investor institusi. Investor institusional merupakan investor besar, seperti: bank, perusahaan investasi, perusahaan asuransi, dan institusi keuangan lainnya yang memiliki dana dalam jumlah relatif besar yang dapat diinvestasikan dalam sejumlah saham perusahaan yang berbeda. Oleh karenanya, investor-investor seperti ini sangat mempengaruhi corporate governance roles dimana corporate governance pada dasarnya berperan dalam mereduksi agency cost.

Berdasarkan rekapitulasi hasil penelitian sebagaimana ditunjukkan pada Tabel 2 di atas dapat dikemukakan bahwa Kepemilikan Institusi (KI) berpengaruh positip dan signifikan ternadap Dividen Payout Ratio (DPR) dengan nilai koefisen regressi distandardisasi sebesar 0,144 dan probabilitas sebesar 0,047. Artinya, dengan bertambahnya Kepemilikan Institusi (KI) akan mengakibatkan Dividen Payout Ratio (DPR) semakin besar. Sebaliknya, dengan berkurangnya Kepemilikan Institusi (KI) akan mengakibatkan Dividen Payout Ratio (DPR) semakin rendah.

Hasil penelitian ini mendukung konsep bahwa kebijakan dividen dapat dipergunakan untuk mereduksi biaya agensi. Dengan adanya pemisahan antara prisipal dan agen mengakibatkan terjadinya konflik kepentingan antara shareholders dengan manajer sehingga timbul biaya agensi, dan biaya agensi ini akan berdampak pada semakin rendahnya imbal hasil bagi investor. Oleh karenanya, kebijakan dividen dipergunakan untuk menurunkan biaya agensi tersebut.

Selain itu, hasil penelitian ini juga mendukung konsep bahwa agents mengirimkan informasi kepada principal tentang nilai perusahaan melalui pembayaran dividen. Pembayaran dividen juga merupakan signal yang paling baik bagi investor institusi sebab investor tersebut lebih berperan dalam memonitor kinerja perusahaan sehingga investor institusi cenderung menginginkan distribusi laba dalam bentuk dividen dengan persentase yang lebih besar. Oleh karena itu, hasil penelitian ini selaran dengan hasil penelitian yang dilakukan oleh Shleifer dan 
Vishny (1986); Short et al. (2002); Ullah (2012) yang menunjukkan bahwa struktur kepemilikan saham berhubungan positip dan signifikan dengan kebijakan dividen.

Selanjutnya, biaya agensi dapat diturunkan jika kepemilikan saham insider (managers, directors, dan executive officers yang lain) meningkat sebab kenaikan kepemilikan saham insider dapat membantu menyelaraskan kepentingan antaa managers dan shareholders. Dengan proporsi managerial ownership, penggunaan dividen sebagai alat untuk menurunkan biaya agensi dapat diturunkan.

Berdasarkan rekapitulasi hasil penelitian sebagaimana ditunjukkan pada Tabel 2 di atas dapat dikemukakan bahwa Kepemilikan Manajerial (KM) tidak berpengaruh signifikan ternadap Dividen Payout Ratio (DPR). Hal ini ditunjukkan oleh nilai koefisen regressi distandardisasi sebesar -0,027 dan probabilitas sebesar 0,708. Namun demikian, dengan memperhatikan arah koefisen regressi distandardisasi variabel Kepemilikan Manajerial (KM), hasil penelitian ini sesuai dengan yang diharapkan hanya saja tidak signifikan secara statistik. Artinya, dengan bertambahnya Kepemilikan Manajerial (KM) akan mengakibatkan Dividen Payout Ratio (DPR) semakin rendah. Sebaliknya, dengan berkurangnya Kepemilikan Manajerial (KM) akan mengakibatkan Dividen Payout Ratio (DPR) semakin besar.

Dengan memasukkan variabel kontrol terhadap model analisis sebagaimana ditunjukkan pada Tabel 3 di atas dapat dikemukakan bahwa Kepemilikan Institusi (KI) berpengaruh positip dan signifikan terhadap Dividen Payout Ratio (DPR) dengan koefisien regressi distandardisasi sebesar 0,144 dan probabilitas sebesar 0,047. Variabel bebas yang kedua adalah Kepemilikan Manajerial (KM). Kepemilikan Manajerial (KM) tidak berpengaruh signifikan terhadap Dividen Payout Ratio (DPR) dengan koefisien regressi distandardisasi sebesar -0,010 dan probabilitas sebesar 0,88.

Dengan memasukkan variabel kontrol terhadap model analisis dan tanpa variable kontrol, pengaruh Kepemilikan Institusi (KI) dan Kepemilikan Manajerial (KM) terhadap Dividen Payout Ratio (DPR) tetap dengan nilai koefisien regressi distandardisasi relatif sama. Kondisi ini menggambarkan bahwa Kepemilikan Institusi (KI) dan Kepemilikan Manajerial (KM) merupakan varaiabel yang konsisten pengaruhnya terhadap Dividen Payout ratio (DPR).

Variabel ketiga adalah Ukuran Perusahaan (UP). Hasil penelitian menunjukkan bahwa Ukuran Perusahaan (UP) berpengaruh positip dan signifikan terhadap Dividen Payout Ratio (DPR) dengan nilai koefisien regressi distandardisasi sebesar 0,162 dan probabilitas adalah 0,023. Dalam berbagai literatur dikemukakan bahwa perusahaan yang semakin besar mengakibatkan probabilitas kebangkrutan suatu perusahaan semakin rendah. Kondisi ini terjadi disebabkan perusahaan-perusahaan yang besar cenderung terdiversifikasi secara baik sehingga perusahaan cenderung memiliki kemampuan dalam membayar dividen dalam jumlah yang lebih besar. Oleh karenanya, Ukuran Perusahaan (UP) memiliki hubungan kausal yang positip dengan Dividend Payout Ratio (DPR). Oleh karenanya, hasil penelitian ini selaras dengan hasil penelitian yang dilakukan oleh Ramli (2010) yang menemukan bahwa size perusahaan berpengaruh positip dengan kebijakan dividen.

Selain size perusahaan, struktur modal (leverage) juga dipergunakan sebagai variabel kontrol. Leverage dipergunakan sebagai variabel kontrol disebabkan leverage dapat meningkatkan shareholders return tetapi dengan tingkat risiko yang lebih besar untuk menghindari likuidasi dan mempertahankan posisi likuiditas serta arus kas yang pada akhirnya akan mempengaruhi pembayaran dividen. Dengan demikian dapat dikemukakan bahwa leverage diharapkan memiliki hubungan kausal yang negatip dengan dividend payout ratio. 
Menurut Jensen dan Meckling (1976), dan Jensen (1986), leverage keuangan berperan penting dalam memonitor manajer sehingga berperan dalam mereduksi agency cost atas konflik antara shareholders dan managers sehingga meningkatkan nilai perusahaan. Jensen (1986) menyimpulkan bahwa penggunaan debt dapat mereduksi kebutuhan penggunaan dividend untuk mengurangi konflik kepentingan sehingga diprediksi hubungan kausal negatip antara debt dan dividend. Hasil penelitian menunjukkan bahwa Struktur Modal tidak berpengaruh terhadap Dividen Payout ratio (DPR) dengan nilai koefisien regressi distandardisasi sebesar 0,042 dan probabilitas adalah 0,555. Namun demikian, dengan memperhatikan koefisien arah dari variabel Struktur Modal (SM), hasil penelitian ini sesuai dengan yang diharapkan, hanya saja tidak signifikan secara statistik.

Variabel kontrol berikutnya adalah Profitabilitas Perusahaan (PP). Perusahaanperusahaan yang berhasil menghasilkan laba akan terhindar dari kebangkrutan sehingga diharapkan bahwa profitabilitas perusahaan berhubungan positip dengan kebijakan dividen. Hasil penelitian menunjukkan bahwa Profitability Perusahaan (PP) tidak berpengaruh terhadap Dividen Payout Ratio (DPR) dengan koefisien regressi distandardisasi sebesar -0,008 dan probabilitas sebesar 0,913 .

\section{Kesimpulan}

\section{KESIMPULAN DAN SARAN}

Berdasarkan hasil penelitian dan pembahasan dapat dikemukakan beberapa kesimpulan sebagai berikut:

Pertama, kepemilikan institusi sebelum dan sesudah dimasukkan variabel kontrol berpengaruh positip dan signifikan terhadap dividen payout ratio dengan nilai koefisien regressi distandardisasi relatif sama. Kedua, kepemilikan manajerial sebelum dan sesudah dimasukkan variabel kontrol tidak berpengaruh signifikan terhadap dividen payout ratio dengan nilai koefisien regressi distandardisasi relative sama. Ketiga, ukuran perusahaan berpengaruh positip dan signifikan terhadap dividen payout ratio. Keempat, struktur modal dan profitability perusahaan tidak berpengaruh signifikan terhadap dividen payout ratio.

\section{Saran}

Berdasarkan kesimpulan tersebut dapat dikemukakan bebera saran sebagai berikut:

Pertama, kebijakan dividen dapat dipergunakan oleh perusahaan-perusahaan yang telah go public sebagai mekanisme dalam menurunkan biaya agensi. Kedua, diperlukan penelitian lanjutan tentang dampak struktur kepemilikan perusahaan terhadap dividen payout ratio dengan memasukkan struktur kepemilikan saham yang lainnya, seperti: pemerintah, kepemilikan asing, maupun konsentrasi kepemilikan. Selain hal tersebut, dibutuhkan juga variable control yang lebih banyak untuk mengecek pengaruh struktur kepemilikan terhadap kebijakan dividen untuk menghasilkan suatu kesimpulan yang general untuk semua industri. 


\section{DAFTAR PUSTAKA}

Ahmed, H and J. Attiya. 2009. Dynamics and Determinants of Dividend Policy in Pakistan (Evidence from Karachi Stock Exchange Non Financial Firms), International Journal of Finance and Economics, Issue 25, 148-171.

Al-Malkawi, HN. 2007. Determinants of Corporate Dividend Policy in Jordan: An Application of the Tobit Model, Journal of Economic E Administrative Sciences, vol. 23, No. 2, 44-70.

Arshad, Zeeshand; Yaris Akram; Maryam Amjad and Muhammad Loman, 2013. Ownership Structure and Dividend Policy, Interdisciplinary Journal of Conteporary Research in Business, Vol 5, No. 3.

Beiner Stefan, Drobetz Wolfgang, Schmid. M., and Zimmermann Heinz, 2006. An Integrated Framework of Corporate Governance and Firm Valuation. European Financial Management, Vol. 12, No. 2, 249 - 283.

Bhattacharya, S. 1980. Nondissipative Signaling Structures and Dividend Policy, Quarterly. Journal of Economics, XCV(1), 1-24.

Chen ZH; Cheung Y; Stouraitis A; and Wong A. 2005. Ownership Concentration, Firm Performance and Dividend Policy in Hongkong, Pac. Bas. Financ. J., 13: 431-449.

Eckbo, B.E., and Verma, S., 1994. Managerial Share Ownership, Voting Power, and Cash Dividend Policy. Journal of Corporate Finance 1, 33- 62.

Indriantoro, Nur dan Bambang Supomo, 1999. Metodologi Penelitian Bisnis untuk Akuntansi dan Manajemen, Edisi Pertama, BPFE, Yogyakarta.

Institute for Economic and Financial Research, 2011, Indonesian Capital Market Directory, Jakarta.

Jennings, W. W., K. Schnatterly and P. J. Seguin, 2002, Institutional Ownership, Information and Liquidity, Innovation in investment and Corporate finance 7, $41-47$.

Jennings, William W; Karen Schnatterly; and Paul J. Seguim, 2002, Institutional Ownership, Information and Liquidity, Innovation in Investment and Corporate Finance 7, 41 - 71.

Jensen MC, and Meckling W. 1976, Theory of the Firm: Managerial Behavior, Agency Costs, and Ownership Structure', Journal of Financial Economy, vol. 3, pp. 305-360.

Jensen, M. 1986. Agency Costs of Free-Cash-Flow, Corporate Finance, and Takeovers. Am. Econ. Rev., 76: 323-329.

Kouki M, and Guizani M. 2009, 'Corporate Governance and dividend policy in Poland', Warsaw School of Economics, World Economy Research Institute, Al. Niepodlegosci, Warsaw, vol. 162, pp. 02- 554.

Li, Kai, and Xinlei Zhao. 2008. Asymmetric Information and Dividend Policy, Financial Management, 37(4), 673-694

Rajan, Raghuram G., and L. Zingales. 1995. What Do We Know About Capital Structure? Some Evidence from International Data, Journal of Finance 50, 1421-1460. 
Ramli, Nathasa Mazna, 2010, Ownership Structure and Dividend Policy: Evidence from Malaysian Companies, International Review of Business Research Papers, Vol 6. No. 1. $170-180$.

Shleifer, Andrei and Robert W. Vishny. 1986. Large Shareholders and Corporate Control. The Journal of Political Economy. 94(3):461.

Short H., Zhang H., and Keasey K. 2002. The Link between Dividend Policy and Institutional Ownership. J. Corp. Financ., 8: 105-122.

Syakhroza, H. Akhmad, 2005. Corporate Governance: Sejarah dan Perkembangannya, Teori, Model, dan Sitem Governance serta Aplikasinya pada Perusahaan BUMN, Fakultas Ekonomi Universitas Indonesia, Jakarta.

Ullah, Hamid; Fida Asma; Khan, Shafiullah, 2012, The Impact of Ownership Structure on Dividend Policy Evidence from Emerging Markets KSE-100 Index Pakistan, International Journal of Business and Social Science, Vol 3, No. 9, Hal. 298-

Van Horne, James C. 1991. Financial Management and Policy, Eighth Edition, Prentice-Hall of India Private Limited New Delhi.

Wen, Yuan.and Jia, Jingyi. 2010. Institutional Ownership, Managerial Ownership and Dividend Policy in Bank Holding Companies. International Review of Accounting, Banking and Finance, Vol 2, No. 1, Spring 2010 Page 8 21.

Zeckhauser, R. and J. Pound, 1990, Are Large Shareholders Effective Monitors? An Investigation of Share Ownership and Corporate Governance, in: R. Hubbard, ed., Asymmetric Information, Corporate Finance and Investment (University of Chicago Press, Chicago) 149-180. 